Prasad K \& Jha AK 2010 Biosynthesis of CdS nanoparticles: an improved green and rapid procedure. Journal of Colloid Interface Science 342 68-72

Rial D, Vázquez JA \& Murado MA 2011 Effects of three heavy metals on the bacteria growth kinetics: a bivariate model for toxicological assessment. Applied Microbiology and Biotechnology 90 10951109

Salim AB, Badawy IH \& Kassem SS 2011 Effect of lactic acid bacteria against heavy metals toxicity in rats. Journal of American Science 7 264-274

Satarug S, Garrett SH, Sens MA \& Sens DA 2010 Cadmium, environmental exposure, and health outcomes. Environmental and Health Perspectives 118 182-190

Urban PL \& Kuthan RT 2004 Application of probiotics in the xenobiotic detoxification therapy. Nukleonika 49 43-45
World Health Organization (WHO) 1989 Evaluation of Certain Food Additives and Contaminants. Thirty-third Report of the Joint FAO/WHO Expert Committee on Food Additives. WHO Technical Report Series 776. Available: http://www.who.int/ipcs/publications/jecfa/reports/en/index. html [accessed 2nd October 2013]

World Health Organization (WHO) 2006 Guidelines for Drinking-water Quality. Vol. 1, Recommendaciones-3rd ed. Available in: http://www. who.int/water_sanitation_health/dwq/gdwq3rev/en/index.htm

Zhai Q, Wang G, Zhao J, Liu X, Tian F, Zhang H \& Chen W 2013 Protective effects of Lactobacillus plantarum CCFM8610 against acute cadmium toxicity in mice. Applied and Environmental Microbiology $\mathbf{7 9}$ 1508-1515

Zheng Y, Lu Y, Wang J, Yang L, Pan C \& Huang Y 2013 Probiotic properties of Lactobacillus strains isolated from Tibetan kefir grains. PLOS ONE 8 e69868

Journal of Dairy Research (2014) 81287 . C Proprietors of Journal of Dairy Research 2014

doi:10.1017/S0022029914000351

\title{
ERRATUM
}

\section{Removal of cadmium by Lactobacillus kefir as a protective tool against toxicity - ERRATUM}

\author{
Esteban Gerbino, Paula Carasi, E. Elizabeth Tymczyszyn and Andrea Gómez-Zavaglia
}

doi:10.1017/S0022029914000314 Published Cambridge University Press, 24 June 2014

The y-axis of Fig. 6 should read \% Viable cells (not Visible cells as printed).

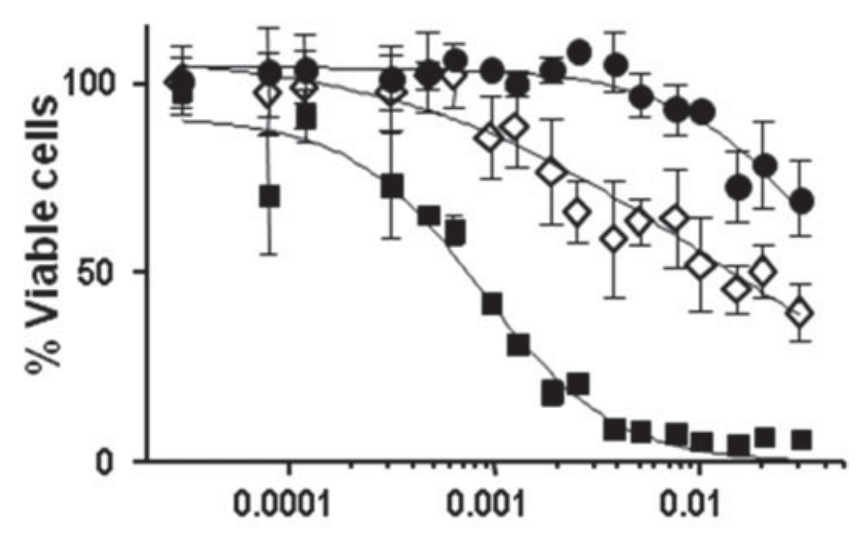

Cadmium concentration ( $\mathrm{mM})$

\section{Reference}

Gerbino et al. 2014 Removal of cadmium by Lactobacillus kefir as a protective tool against toxicity. Journal of Dairy Research $81280-287$ 